\title{
HPLC-UV and LC-MS Analysis of Quinonemethides Triterpenes in Hydroalcoholic Extracts of "espinheira santa" (Maytenus aquifolium Martius, Celastraceae) Leaves
}

\author{
Ana C. Nossack, Renata M. dos S. Celeghini, Fernando M. Lanças and Janete H. Yariwake* \\ Instituto de Química de São Carlos, Universidade de São Paulo, CP 780, 13560-970 São Carlos - SP, Brazil
}

\begin{abstract}
Alguns triterpenos quinonametídicos são conhecidos pela sua citotoxicidade, havendo relatos destas substâncias em várias espécies do gênero Maytenus (Celastraceae), inclusive em Maytenus aquifolium Martius, uma das espécies conhecidas no Brasil como "espinheira santa". Com o objetivo de dispor de um método analítico útil na avaliação da qualidade de medicamentos fitoterápicos de "espinheira santa", foi desenvolvido um procedimento de análise por cromatografia líquida de alta eficiência com detector ultravioleta (CLAE-UV). Foi realizada a quantificação dos triterpenos quinonametídicos maitenina e pristimerina, nos extratos hidroalcoólico e aquoso ("chá") das folhas e das cascas das raízes de M. aquifolium. As análises por cromatografia líquida acoplada à espectrometria de massas (LC-MS) usando a interface de ionização química à pressão atmosférica (APCI), confirmaram a presença de maitenina e pristimerina nos extratos hidroalcoólicos de $M$. aquifolium, enquanto que nos extratos aquosos estes triterpenos estão abaixo do limite de detecção.
\end{abstract}

Some quinonemethide triterpenes are known for their cytotoxicity, and the presence of these compounds has been reported in several Maytenus (Celastraceae) species, including Maytenus aquifolium Martius, one of the species known in Brazil as "espinheira santa". A quantitative HPLCUV procedure was therefore developed with the purpose of devising a useful analytical method for evaluating the quality of "espinheira santa"-based phytomedicines. Quinonemethide triterpenes pristimerin and maitenin were quantified in hydroalcoholic and aqueous extracts ("teas") prepared from the leaves and root bark of M. aquifolium. Analyses by liquid chromatography coupled to mass spectrometry (LC-MS), using the atmospheric pressure chemical ionization (APCI) interface, provided unequivocal confirmation of the presence of maitenin and pristimerin in M. aquifolium hydroalcoholic extracts, although these compounds were below detection limits in aqueous extracts.

Keywords: Maytenus aquifolium Martius, Celastraceae, quinonemethide triterpenes, HPLCUV, LC-MS

\section{Introduction}

Maytenus aquifolium Martius and M. ilicifolia Martius (Celastraceae) are both known in Brazil as "espinheira santa", and systematic studies are focusing on their use as phytomedicines for the treatment of gastric ulcers and gastritis. ${ }^{1-3}$ Reports on studies of Maytenus aquifolium include pharmacology, ${ }^{4}$ phytochemistry of flavonoids ${ }^{5}$ and sesquiterpene ${ }^{6}$ pyridine alkaloids biosynthesis studies ${ }^{7}$ and authentication of phytomedicines (leaf samples) by chromatographic analysis $\left(\mathrm{GC},{ }^{8} \mathrm{HPTLC}^{9}\right)$.

Use of any medicinal plant as a phytomedicine requires the prior evaluation of its efficacy and safety. Toxicological

* e-mail: janete@iqsc.usp.br essays of Maytenus aquifolium leaf extracts spray-dried with $70 \%$ ethanol have indicated no significant toxicity in mice. ${ }^{2}$ However, reports in the literature on quinonemethide triterpenes (displaying cytotoxic activity and therefore containing potentially toxic compounds) in Maytenus samples suggest that "espinheira santa"-based phytomedicines must be carefully investigated. These compounds have been quantified by HPLC-UV external standard in cell cultures (callus extracts) of Maytenus aquifolium, ${ }^{10}$ and HPLC quantification of quinonemethide triterpenes in the root bark of Maytenus ilicifolia (another species known as "espinheira santa") has also been reported. ${ }^{11}$ However, these HPLC procedures offer a very limited assessment of the safety of Maytenus-based phytomedicines, since they are based mainly on hydroalcoholic or aqueous leaf extracts, ${ }^{2,12}$ which contain interfering compounds different from those found in less polar root or callus extracts. 
Aiming to come up with an analytical method suitable for analyzing quinonemethide triterpenes in small concentrations in complex mixtures such as hydroalcoholic leaf extracts, we have developed an HPLC-UV procedure which is described herein. This method has proved feasible for the analysis of leaf infusions (aqueous extracts, known popularly as 'tea'), and has also been applied to commercial "espinheira santa" samples in order to illustrate the method's potential for routine (quality control) analyses.

LC-MS analyses were also performed to confirm the presence of the triterpenes in question in aqueous and hydroalcoholic Maytenus aquifolium leaf extracts. The LC-MS method may be an alternative procedure for assessing the quality of end phytomedicines, in the selective analysis of low concentrations of toxic plant compounds. $^{13}$

\section{Experimental}

\section{Plant material}

The root bark and leaves used as reference for the development of the analytical method were kindly furnished by Dr. Ana Maria Soares Pereira (UNAERP, Ribeirão Preto, SP, Brazil), and were taken from specimens originating from seedlings of Maytenus aquifolium raised in UNAERP's Biotechnology Department greenhouse and cultivated under good agricultural practices at UNAERP's farm in Ribeirão Preto, SP, Brazil. Voucher samples are deposited at UNAERP herbarium under number HPMU0755 . The plant material was dried at $40{ }^{\circ} \mathrm{C}$ under forced ventilation for $24 \mathrm{~h}$, then pulverized and sieved (70 mesh) prior to its storage in closed bottles protected from light.

\section{Chemicals}

The solvents employed were distilled in the laboratory (extraction of plant material), having an analytical grade (Merck, Darmstadt, Germany) or HPLC grade (Mallincrodt, Kentucky, U.S.A.). The water was purified in a Milli-Q system (Millipore).

Extraction and purification of the quinonemethide triterpenes standards

Powdered root bark (450 g) was extracted three times by maceration with methanol $(5.0 \mathrm{~L}$ each) at room temperature. The methanol extracts were mixed and vacuum-dried by evaporation (177.2 g, corresponding to a total yield of $39.4 \%$ ). The residue was then divided between aqueous methanol $\left(2 \mathrm{H}_{2} \mathrm{O}: 1 \mathrm{CH}_{3} \mathrm{OH}\right)$ : chloroform
(1:1, $0.5 \mathrm{~L}$ each). The chloroform layer was vacuum-dried by evaporation and an aliquot of $30.0 \mathrm{~g}$ was applied to a column filled with $300 \mathrm{~g}$ of a 1:1 mixture of silica gel (63 - $210 \mathrm{~mm}$ ) and Florisil (both Merck, Darmstadt, Germany). The column had the following dimensions: internal diameter $=5.0 \mathrm{~cm}$; length around $110 \mathrm{~cm}$; dead volume $600 \mathrm{~mL}$. Elution began with hexane $(1.0 \mathrm{~L})$, followed by a hexane-ethyl acetate gradient (99:1 v/v, 98:2 etc; $0.5 \mathrm{~L}$ each mixture), then by an ethyl acetate-methanol gradient (99:1 v/v, 98:2 etc until 1:1; 0.5 L each mixture), and concluded with pure methanol for washing (around $2 \mathrm{~L}$ ), in a total of 154 fractions. After the TLC analysis, fractions \# 49 to $62(248 \mathrm{mg})$ and \# 63 to $77(191 \mathrm{mg})$ were joined and fractionated separately by CC (120 g silica gel $40-$ $63 \mathrm{~mm}$, Merck), under $\mathrm{N}_{2}$ pressure $(0.5 \mathrm{~atm})$ and eluted with hexane: ethyl acetate 7:3. The CC of fractions \# 49 to 62 yielded 100 sub-fractions of $11 \mathrm{~mL}$ each and, after the TLC analysis, sub-fractions \# 58 and 59 were joined, giving maitenin $(1,107 \mathrm{mg})$. The CC of fractions \# 63 to 77 gave 44 sub-fractions of $11 \mathrm{~mL}$ each and, after the TLC analysis, sub-fractions 15 to 19 were joined, yielded pristimerin $(\mathbf{2}, 24 \mathrm{mg})$. The identities of $\mathbf{1}$ and $\mathbf{2}$ were confirmed by comparing their spectroscopic data (UV, IR, $\mathrm{MS},{ }^{1} \mathrm{H}$ and ${ }^{13} \mathrm{C}$ NMR) with data available in the literature. ${ }^{14}$

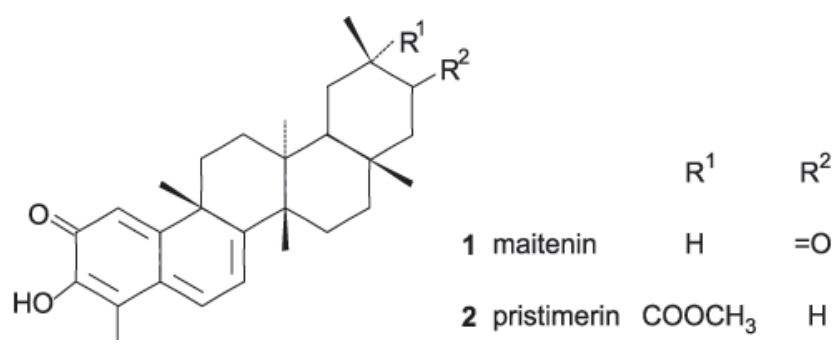

Figure 1. Structures of the triterpenes of Maytenus aquifolium determined in this investigation. 1, maitenin; 2, pristimerin.

Sample preparation for chromatographic (HPLC and LC$M S)$ analysis

Hydroalcoholic extracts of $M$. aquifolium were prepared by macerating powdered leaves or root bark $\left(1.0 \mathrm{~g}\right.$ ) with ethanol-water (ratio of $1: 1 \mathrm{v} / \mathrm{v}, 10 \mathrm{~mL}, 50^{\circ} \mathrm{C}$, $10 \mathrm{~min}$ ). The extract was filtered and the volume adjusted to $10.0 \mathrm{~mL}$, after which it was extracted with chloroform $(5.0 \mathrm{~mL})$, the layers separated and the upper hydroalcoholic layer filtered and analyzed by HPLC. The aqueous extracts of $M$. aquifolium were prepared by infusing powdered leaves or root bark $(1.0 \mathrm{~g})$ in boiling distilled water $(100 \mathrm{~mL})$ and allowing the infusion to steep in a covered flask for $15 \mathrm{~min}$. The extract was then filtered, lyophilized 
and resuspended in $1.0 \mathrm{~mL}$ methanol, after which the solutions were filtered and analyzed directly by HPLC.

\section{HPLC analyses}

HPLC-UV analyses were performed using a Shimadzu (Shimadzu, Tokyo, Japan) liquid chromatography modular system consisting of two LC-10AD pumps, an UV Shimadzu SPD M10A diode array UV detector, and an LC WorkStation Class LC10 system for data processing. The samples were introduced using an injection valve fitted with a $10 \mu \mathrm{L}$ loop (Rheodyne, California, USA). The mobile phase consisted of aqueous trifluoroacetic acid $1 \%(\mathrm{v} / \mathrm{v})$ methanol (8:2, isocratic mode) at a flow rate of $1 \mathrm{~mL} \mathrm{~min}^{-1}$. A C-18 column (Supelcosil, $250 \mathrm{~mm}$ x $4.6 \mathrm{~mm}$ x $5 \mu \mathrm{m}$, Supelco, Bellefonte, USA) fitted with a guard column (C$18,20 \mathrm{~mm} \times 4.6 \mathrm{~mm} \times 5 \mu \mathrm{m}$, Supelco) was utilized at an oven temperature of $33{ }^{\circ} \mathrm{C}$. UV detection was performed at $430 \mathrm{~nm}$.

A quantitative analysis was done by the external standard method, plotting calibration curves for each triterpene at concentrations of 0.05, 0.10, 0.20, 0.30, 0.40, 0.5 and $1.0 \mathrm{mg} \mathrm{mL}^{-1}$ in methanol. Each determination was carried out in triplicate. Concentration values were uncorrected, assuming, for purposes of calculation, that each standard was $100 \%$ pure. The purity of the standards was confirmed by HPLC analysis performed under the above described chromatographic conditions. Each standard peak was found to be $100 \%$ pure according to criteria of peak purity (UV/DAD spectra) measurements plus automatic integration of the chromatogram's peaks using the Shimadzu equipment software.

The LOD (limit of detection) was determined by injecting standard solutions of maitenin and pristimerin under the HPLC conditions described in sufficient amounts to obtain a signal-to-noise $(\mathrm{S} / \mathrm{N})$ ratio of $3: 1 .{ }^{15}$

\section{LC-MS analysis}

LC-MS analyses were done on a Shimadzu liquid chromatography modular system consisting of two LC10AD pumps coupled to an LC/MS QP 8000 quadrupole detector. The data were processed using Shimadzu's Class8000 system. Analyses using the APCI (atmospheric pressure chemical ionization) interface were performed in a C-18 column (Supelcosil $250 \mathrm{~mm} \times 4.0 \mathrm{~mm} \times 5 \mu \mathrm{m}$ ) fitted with a guard column (C-18, $20 \mathrm{~mm} \times 4.0 \mathrm{~mm} \times 5 \mu \mathrm{m})$, both Supelco, at an oven temperature of $35^{\circ} \mathrm{C}$. The samples were introduced using a Rheodyne injection valve fitted with a $20 \mu \mathrm{L}$ loop. The mobile phase consisted of aqueous formic acid $1 \%(\mathrm{v} / \mathrm{v})$ : methanol with formic acid $1 \%(8: 2$, isocratic mode) at a flow rate of $1 \mathrm{~mL} \mathrm{~min}^{-1}$. The mass detector was operated in the positive mode with nitrogen as the nebulizer gas at a flow rate of $2.0 \mathrm{~L} \mathrm{~min}^{-1}$, under the following conditions: the capillary temperature was $230{ }^{\circ} \mathrm{C}$; deflector voltage, $+47 \mathrm{~V}$; CDL voltage and temperature, $-28 \mathrm{~V}$ and $230{ }^{\circ} \mathrm{C}$; probe voltage (corona discharge) and temperature, $+3.5 \mathrm{~V}$ and $400{ }^{\circ} \mathrm{C}$; acquisition range, $100-700 \mathrm{~m} / z$ at $2.0 \mathrm{scan} \mathrm{s}^{-1}$. Analyses using ESI (electrospray ionization) interface were done under the same chromatographic conditions as described for the APCI analysis, except for the guard column, which was not used in the ESI analysis. The mass detector conditions were: nitrogen as the nebulizer gas at a flow rate of $4.5 \mathrm{~L} \mathrm{~min}^{-1}$; deflector voltage, $+54 \mathrm{~V}$; CDL voltage and temperature, - $10 \mathrm{~V}$ and $230{ }^{\circ} \mathrm{C}$; probe voltage (corona discharge), $+4.5 \mathrm{~V}$; acquisition range, $100-700 \mathrm{~m} / \mathrm{z}$ at $2.0 \mathrm{scan} \mathrm{s} \mathrm{s}^{-1}$.

\section{Results and Discussion}

The development of the analytical method took into account both the processing of Maytenus leaves for the preparation of phytomedicines (hydroalcoholic extracts) and the traditional use of the plant in the form of "teas" (aqueous extracts), resulting in the simplest possible procedure for quantitative analysis and therefore easily applicable in routine analyses. The direct HPLC analysis of aqueous extracts was adopted since none of the tested cleanup strategies for aqueous extracts (namely, liquid-liquid extraction and solid phase extraction with several adsorbents such as Florisil, silicagel and Amberlite) showed any significant improvement in removing matrix interferences.

Extraction of root bark was done in order to purify standards for quantitative analysis, because maitenin and pristimerin (peaks 1 and 2, respectively, in Figure 2) were not commercially available. Regression equations for maitenin and pristimerin were, respectively, $y=-8.9310^{5}$ $+3.1910^{6} x(r=0.999)$ and $y=7.9410^{6}+1.5410^{7} x(r=$ 0.999). LOD were $20 \mu \mathrm{g} \mathrm{mL}^{-1}$ for maitenin and $40 \mu \mathrm{g} \mathrm{mL}^{-1}$ for pristimerin. An analysis of aqueous extracts of root bark (Figure 2a) was made to adjust the analytical conditions, since leaf extracts had to be spiked due to the low content of the triterpenes under study. In comparison with root bark, the leaves have a lower content of these triterpenes (Table 1), which are found only in hydroethanolic extract (Figure 2b); on the other hand, the absence of triterpene in aqueous extracts was also confirmed by spiking (Figure 2c). Recovery experiments performed utilizing triterpenes standards, at the same concentration level found on Maytenus samples, gave low but repeatable results for the studied compounds, namely $(85.48 \pm 0.05) \%$ for maitenin and $(56.86 \pm 0.28) \%$ for pristimerin. 

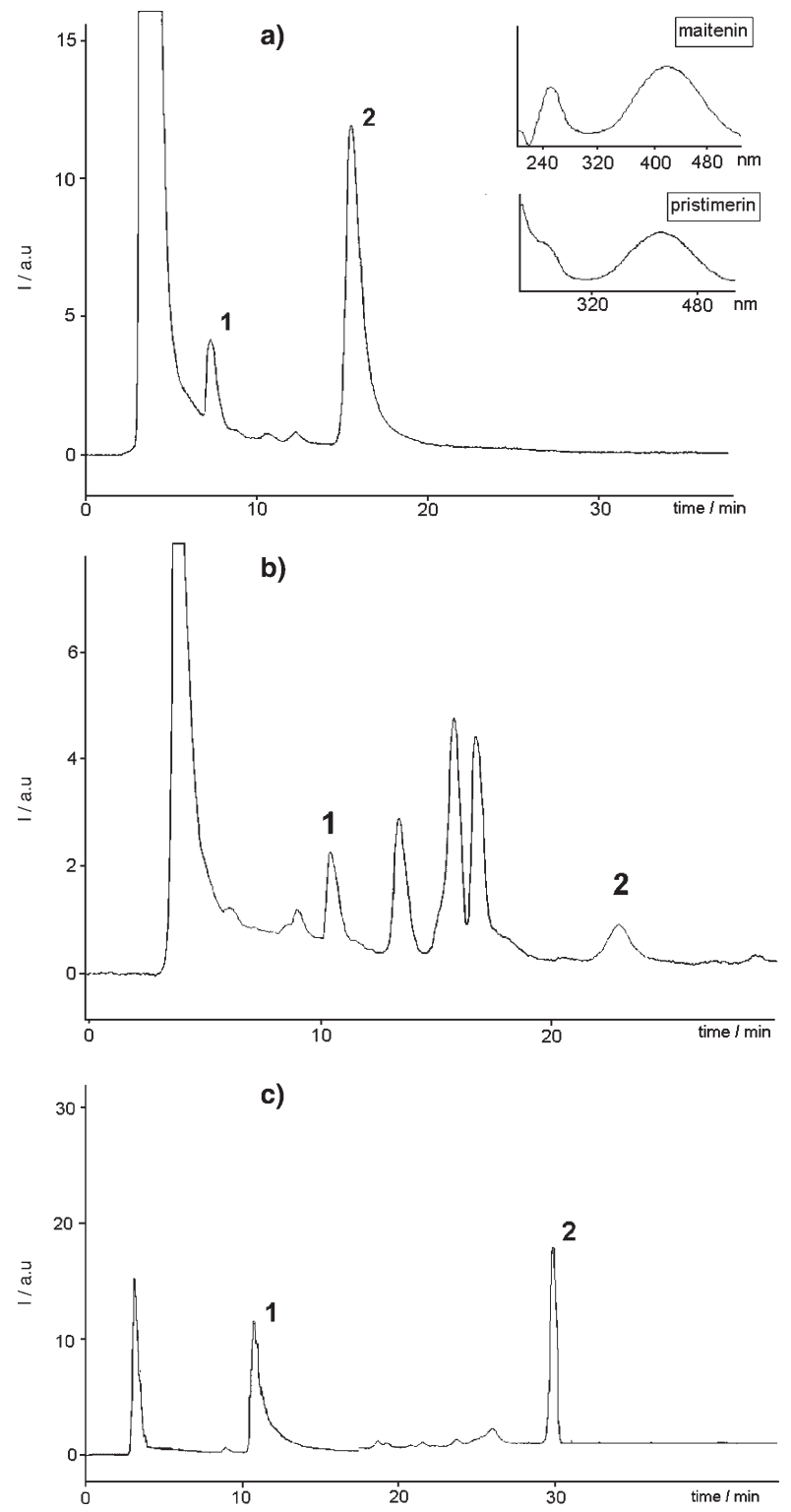

Figure 2. Chromatogram (HPLC-UV, detection at $430 \mathrm{~nm}$; for other chromatographic conditions see HPLC analysis) of typical Maytenus aquifolium extracts. Identification of peaks: 1, maitenin; 2, pristimerin. Peaks 1 and $\mathbf{2}$ were identified by the comparison of their retention time and their UV spectra with those of standards injected at the same chromatographic conditions. (a) aqueous extracts of root bark, expansion: UV/DAD spectra of $\mathbf{1}$ and 2; (b) hydroalcoholic leaf extract. (c) aqueous leaf extract spiked with $\mathbf{1 + 2}, 1 \mathrm{mg} \mathrm{mL}^{-1}$ each.

LC-MS analyses were carried out exploring the selective monitoring of representative ions of the quinonemethide triterpenes under study in order to confirm the presence/ absence of these compounds in Maytenus extracts. Firstly, triterpenes standards were tested with the purpose of choosing the most appropriate interface for the analysis of these compounds in extracts. The chromatographic conditions had to be changed, since ESI and APCI interfaces require a smaller column $(4.0 \mathrm{~cm}$ i.d. instead of 4.6 in a
Table 1. Content of quinonemethide triterpenes in Maytenus aquifolium leaves (reference samples)

\begin{tabular}{|c|c|c|}
\hline \multirow[b]{2}{*}{ Plant part and extract } & \multicolumn{2}{|c|}{$\begin{array}{c}\text { mean }^{\mathrm{a}} \pm \text { s.d (expressed as mg } \\
\text { triterpene/g dried plant) }\end{array}$} \\
\hline & maitenin, 1 & pristimerin, 2 \\
\hline Leaves - hydroalcoholic extract & $0.20 \pm 0.01$ & $0.08 \pm 0.01$ \\
\hline Leaves - aqueous extract & $(-)$ & $(-)$ \\
\hline Root bark - hydroalcoholic extract & $1.24 \pm 0.06$ & $0.44 \pm 0.04$ \\
\hline Root bark - aqueous extract & $0.64 \pm 0.03$ & $0.36 \pm 0.03$ \\
\hline
\end{tabular}

${ }^{\mathrm{a}} \mathrm{n}=3$; quantitative data are given corrected considering recovery of the extraction and clean-up processes for each triterpene; (-): not detected.

previous HPLC-UV analysis). Moreover, formic acid proved to be more efficient than trifluoroacetic acid for ionizing the triterpenes in question. The best sensitivity was achieved using APCI in the full scan mode (Figure 3), which also produced a lower noise level, allowing for a better confirmation of pseudo-molecular ions $[\mathrm{M}+\mathrm{H}]^{+}$, namely $m / z, 421$ for maitenin and $m / z, 465$ for pristimerin. On the other hand, the ESI required SIM mode analysis, which was carried out by monitoring $[\mathrm{M}+1]^{+}$and $[\mathrm{M}+2]^{+}$ions, respectively, $m / z=421$ and 422 for maitenin and $m / z=465$ and 466 for pristimerin. However, even in the SIM mode, the ESI analyses did not unequivocally confirm the identity of the triterpenes under study. A combination of APCI data plus confrontation of the $\mathrm{tR}$ of maitenin and pristimerin standards under the same LC-MS conditions was therefore
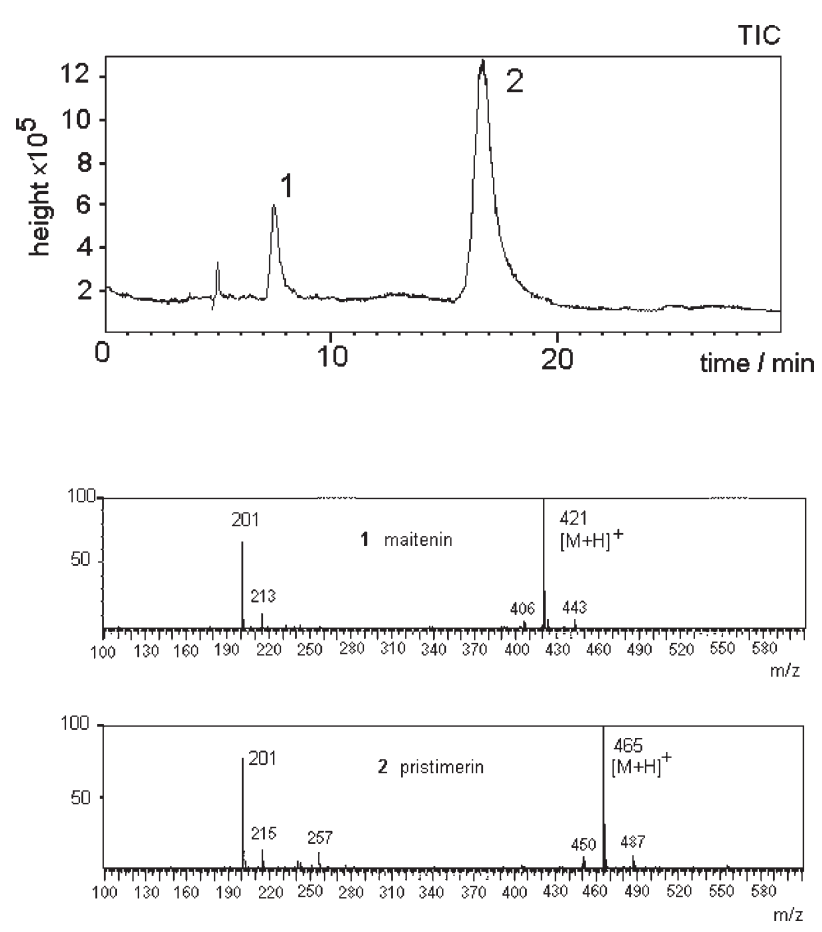

Figure 3. Chromatograms (TIC-LC-APCI-MS, for chromatographic and MS conditions see LC-MS analysis) of a typical hydroalcoholic extract of Maytenus aquifolium leaves. Identification of peaks: 1, maitenin; 2, pristimerin. (a) APCI interface; (b) ESI interface. 
used, which confirmed the presence of these triterpenes only in the hydroalcoholic extracts.

To illustrate an application of the analytical procedure for quantitative analysis developed here, eleven commercial samples of "espinheira santa" were bought in drugstores (in the states of São Paulo and Rio Grande do Sul, Brazil). In order to discard the false samples, they were first compared with authentic Maytenus reference samples, by detailed TLC and GC chromatographic screening procedure. ${ }^{89}$ This previous screening must be done before quantitative analysis, since falsifications are very usual in commercial medicinal plants samples. ${ }^{8}$ At the end of this trial, only five commercial samples were considered authentic and only these authentic ones were subjected to the quantitative analysis (Table 2). These findings also reveal the low level of quality of the commercial samples: a macroscopic examination of the commercial samples revealed extensive mixing with twigs, bark and other extraneous materials, which "diluted" not only maitenin and pristimerin, but also the active compounds.

Table 2. Content of quinonemethide triterpenes in hydroalcoholic extracts of commercial samples of "espinheira santa"

\begin{tabular}{ccc}
\hline Sample $^{\mathrm{a}}$ & $\begin{array}{c}\text { mean }^{\mathrm{b}} \pm \text { s.d (expressed as mg triterpene/g dried plant) } \\
\text { maitenin, 1 } \\
\text { pristimerin, 2 }\end{array}$ \\
\hline$\# 2$ & $0.18 \pm 0.01$ & $0.20 \pm 0.02$ \\
$\# 4$ & $0.74 \pm 0.01$ & $0.63 \pm 0.02$ \\
$\# 5$ & $0.30 \pm 0.02$ & $0.70 \pm 0.01$ \\
$\# 7$ & $0.12 \pm 0.01$ & $1.88 \pm 0.03$ \\
$\# 8$ & $0.04 \pm 0.01$ & $3.58 \pm 0.03$ \\
\hline
\end{tabular}

${ }^{a}$ of the eleven commercial samples purchased in drugstores, only the authentic "espinheira santa" samples are included in this Table; ${ }^{b} \mathrm{n}=3$.

\section{Conclusions}

Quantitative HPLC data, together with LC-MS analyses, confirmed the presence of maitenin and pristimerin in detectable amounts in hydroalcoholic extracts of Maytenus aquifolium leaves. These results indicate the crucial importance of performing accurate safety (toxicological) studies of "espinheira santa" phytomedicines. The analytical method described herein proved suitable for the analysis of leaf extracts, and is therefore considered more appropriate for analyzing "espinheira santa" phytomedicines than other procedures previously reported. ${ }^{10,11}$

\section{Acknowledgements}

The authors are grateful to Prof. Dr. Nídia F. Roque for lending her invaluable support to A.C.N. in the isolation and identification of triterpenes standards at IQ-USP. The authors are also grateful to Dr. Renata Colombo for complementary trials.

The authors also wish to thank Dra. Ana Maria Soares Pereira (UNAERP) for furnishing samples of M. aquifolium leaves and roots; and FAPESP, CNPq and CAPES for their concession of financial aid and grants.

\section{References}

1. Souza-Formigone, M.L.O.; Oliveira, M.G.M.; Monteiro, M.G.; Silveira-Filho, N.G.; Braz, S.; Carlini, E.A.; J. Ethnopharmacol. 1991, 34, 21.

2. Bersani-Amado, C.A.; Massao, L.B.; Baggio, S.R.; Johanson, L.; Albiero, A.L.M.; Kimura, E.; Phytother. Res. 2000, 14, 543.

3. Kimura, E.; Albiero, A.L.M.; Cuman, R.K.N.; Caparroz-Assef, S.M.; Oga, S.; Bersani-Amado, C.A.; Phytomedicine 2000, 7, 117.

4. Gonzalez, F.G.; Portela, T.Y.; Stipp, E.J.; Di Stasi, L.C.; J. Ethnopharmacol. 2001, 77, 41 and references therein.

5. Leite, J.P.V.; Rastrelli, L.; Romussi, G.; Oliveira, A.B.; Vilegas, J.H.Y.; Vilegas, W.; Pizza, C.; J. Agric. Food Chem. 2001, 49, 3796 and references therein.

6. Corsino, J.; Bolzani, V. da S.; Pereira, A.M.S.; França, S.C.; Furlan, M.; Phytochemistry 1998, 49, 2181 and references therein.

7. Corsino, J.; de Carvalho, P.R.F.; Kato, M.J.; Latorre, L.R.; Oliveira, O.M.M.F.; Araújo, A.R.; Bolzani, V. da S.; França, S.C.; Pereira, M.A.S.; Furlan, M.; Phytochemistry 2000, 55, 741.

8. Vilegas, J.H.Y.; Lanças, F.M.; Cervi. A.C.; Phytother. Res. 1994, $8,241$.

9. Vilegas, J.H.Y.; Lanças, F.M.; Wauters, J.N.; Angenot, L.; Phytochem. Anal. 1998, 9, 263.

10. Corsino, J.; Alécio, A.C.; Ribeiro, M.L.; Furlan, M.; Pereira, A.M.S.; Duarte, I.B.; França, S.C.; Phytochem. Anal. 1998, 9, 245.

11. Buffa Filho, W.; Corsino, J.; Bolzani, V. da S.; Furlan, M.; Pereira, A.M.S.; França, S.C. Phytochem. Anal. 2002, 13, 75.

12. Petrovick, P.R.; Jacob, M.; Gaudy, D.; Lopes, C.H.C.; Cad. Farm. 1991, 7 (Supl), L.52.

13. Ndjoko, K.; Wolfender, J.-L.; Hostettmann, K.; J. Chromatogr. B 2000, 744, 249.

14. Gunatilaka, A. A. L; Fernando, C.; Kikuchi, T.; Tezuka, Y.; Magn. Reson. Chem. 1989, 27, 803.

15. http://www.mcclurenet.com/EMEA_PDFs/Q2a.pdf; accessed in September 2003.

Received: March 11, 2003

Published on the web: July 28, 2004

FAPESP helped in meeting the publication costs of this article. 